\title{
Minne suuntaat, Matkailututkimus?
}

\section{Olga Hannonen ja Juho Pesonen, Itä-Suomen yliopisto}

Tällä pääkirjoituksella ja lehden numerolla avautuu uusi Matkailututkimus-lehden päätoimittajuuskausi Itä-Suomen Yliopistossa (UEF). Matkailututkimuksen seura on valinnut uusiksi päätoimittajiksi Olga Hannosen ja Juho Pesosen, ja toimitussihteeriksi Johanna Heinosen. Me vastaamme lehden toimittamisesta vuoden 2021 toisesta numerosta alkaen, vaikka sisällöllisesti matkamuistotyöryhmäläiset ovatkin tehneet päätyön.

Matkailututkimuksen päämääränä on tukea matkailututkimusta erityisesti Suomessa. Tarkoituksenamme on lisätä lehden vaikuttavuutta suomalaisessa matkailukentässä seuraavien vuosien aikana. Matkailussa siirrytään tällä hetkellä ripeästi kohti tietoon perustuvia johtamismalleja. Matkailututkimus-lehdellä on mahdollisuudet nousta merkittäväksi tekijäksi tässä keskustelussa. Luotettavalle tutkimustiedolle on selvä tarve. Näemme, että tulevaisuudessa Matkailututkimus-lehti on keskustelufoorumi toimialan ja tutkimuskentän välillä ja arvokas tietolähde kaikille, jotka haluavat tietää Suomessa tehtävästä matkailututkimuksesta sekä kansainvälisistä matkailutrendeistä.

Tähän tarkoitukseen lehti laajentaa Puheenvuorot-osiota tarjoamaan väylän tutkijoille koota yhteen useamman oman tai tutkimusryhmänsä kansainvälisesti julkaisemat artikkelit yhteen suomenkieliseen artikkeliin, jossa on analysoitu tulosten merkitystä matkailualalle ja -tutkimukselle Suomessa. Tällaisten uusien puheenvuorojen tarkoitus on avata keskustelua aiheesta ja tuoda suomenkieliselle yleisölle tietoa Suomessa tehtävästä kansainvälisestä matkailututkimuksesta ja sen merkityksestä. Lisäksi tässä yhteydessä tullaan nostamaan esille Näkökulmia-osaston roolia keskustelun jatkamiseksi ja mahdollisesti kutsutaan kirjoittajia Näkökulmia-osioon.

Muihin lehden kehitysideoihin kuuluu arvioinnin prosessin nopeuttaminen. Päätoimittajanamme pyrimme antamaan alustavat kommentit kahden viikon kuluessa artikkelin lähettämisestä lehteen tai lähettämään artikkelin vertaisarviointiin.

Suomenkielisissä ja ruotsinkielisissä artikkelissa vaaditaan englanninkielisen abstraktin suomen-, ruotsinkielisen abstraktin lisäksi. Tällä muutoksella haluamme, että suomenkielinen tieteellinen keskustelu ja tutkimustulokset tavoittavat kansainvälistä yleisöä ainakin abstraktin muodossa. Vuonna 2022 lehdessä tapahtuu aikataulumuutoksia. Ensimmäinen numero ilmestyy 1 syyskuuta 2022 ja toinen numero 15 joulukuuta 2022.

Tämä vuoden 2021 toinen numero on Special Issue on Souvenirs. Saimme numeron viimein valmiiksi vierailevien päätoimittajien voimin. Matka tähän oli mutkikas. Tekniset haasteeet viivästyttivät numeron ilmestymistä, mutta päätimme kuitenkin panostaa enemmän artikkeleiden laatuun kuin kiirehtiä niiden julkaisua. Lopputuloksena onkin ai- 
nutlaatuinen kokoelma matkamuistoihin liittyviä artikkeleita ja näkökulmia. Vierailevien päätoimittajien matkamuistotyöryhmä Tuija Hautala-Hirvioja, Hanna Kyläniemi, Maija Mäkikalli ja Heidi Pietarinen kertovatkin Special Issue johdannossa numeronsisällöstä ja heidän näkemyksensä aiheeseen. 